\title{
The influence of genetic factors on personality and coping with stress among healthy late reproductive age women
}

This article was published in the following Dove Press journal:

Clinical Interventions in Aging

\author{
Anna Jurczak (D) \\ Małgorzata Szkup (D) ${ }^{2}$ \\ Krzysztof Safranow (iD) ${ }^{3}$ \\ Agnieszka Samochowiec (D) \\ Sylwia Wieder-Huszla (D) ${ }^{\prime}$ \\ Joanna Owsianowska (D) \\ Elżbieta Grochans (D) $^{2}$ \\ 'Department of Clinical Nursing, \\ Pomeranian Medical University in \\ Szczecin, Szczecin, Poland; ${ }^{2}$ Department \\ of Nursing, Pomeranian Medical \\ University in Szczecin, Szczecin, Poland; \\ ${ }^{3}$ Department of Biochemistry, \\ Pomeranian Medical University in \\ Szczecin, Szczecin, Poland; ${ }^{4}$ Department \\ of Clinical Psychology, Institute of \\ Psychology, University of Szczecin, \\ Szczecin, Poland
}

Background: Psychological stress is a factor which predisposes people to many somatic and mental disorders. Women are at a significantly higher risk of stress than men, and their reactions to stress are stronger. Personality traits are thought to play a special role in the psychology of stress and may be crucial for the choice of a stress-coping strategy. Considering that stress is so common in everyday life, an attempt to understand how stress-coping styles are related to personality and genetic factors acquires special significance.

Purpose: The aim of this study was to analyze stress-coping styles and personality traits in healthy late reproductive age women with regard to genetic factors.

Patients and methods: The study involved 345 healthy late reproductive age women from northwest Poland, whose mean age was $42.3 \pm 4.5$ years. The study was conducted using The Coping Inventory for Stressful Situations, The Neuroticism-Extraversion-Openness FiveFactor Inventory, and genetic testing.

Results: There were neither statistically significant relationships between personality traits and the genotype distribution of the 30-bp VNTR polymorphism in the MAO-A promoter region, nor between stress-coping styles and the genotype distribution of the 30-bp VNTR polymorphism in the $M A O-A$ promoter region.

Conclusion: Based on the results, all personality traits statistically significantly correlated with the choice of task-oriented coping and emotion-oriented coping. Some of personality traits are genetically determined. The choice of a stress-coping style was significantly related to personality traits. A direct influence of genetic factors on the choice of a stress-coping style was not confirmed in our study.

Keywords: stress, personality, polymorphism, women

\section{Introduction}

Psychological stress predisposes to many somatic and mental disorders and significantly modifies the quality of human life. ${ }^{1}$ Women are more exposed to stress than men, and their reactions to stress are stronger. ${ }^{2,3}$

Attempts are made to identify psychosocial and biological factors potentially modifying individual reactions to stress. An interesting research direction is the contribution of the short (s) variant of the 5-HTTLPR functional polymorphism in the serotonin transporter (5-HTT) gene promoter region to a tendency to display negative reactions to stress. ${ }^{4}$ A serotonin-transporter-linked polymorphic region (5-HTTLPR) in SLC 6A4 consists of repetitive sequences of different lengths. A deletion/insertion in
Correspondence: Elżbieta Grochans Department of Nursing, Pomeranian Medical University in Szczecin, Żołnierska 48, 7I-2I 0 Szczecin, Poland

Tel +48914800910

Fax +48 91 4800905

Email grochans@pum.edu.pl 
the promoter region creates short (s) and long (l) alleles, thus deciding about the promoter activity. ${ }^{5}$ A short allele with a 44-bp deletion is associated with a thrice lower transcriptional activity than a long allele with a 44-bp insertion. ${ }^{6}$ The serotonin transporter (5-HTT) gene polymorphism seems to be associated with adaptive skills, such as control of emotions. It is also regarded as one of the genetic factors that may determine psychological distress and psychoemotional deviations. ${ }^{7}$ Another genetic factor analyzed in this study is monoamine oxidase (MAO), which regulates the levels of neurotransmitter amines, controls mood and emotions, and plays a part in the pathophysiology of various neuropsychiatric disorders. ${ }^{8,9}$ A single base modification in the MAO-A gene, resulting in MAO-A deficiency, ${ }^{10}$ involves impulsive aggression, irritability, property destruction, and other types of antisocial behavior. A variable-number tandem repeat (VNTR) polymorphism in the $M A O-A$ promoter region ${ }^{11}$ consists of a $30-\mathrm{bp}$ repeated sequence, which can be present in 3, 3.5, 4, and 5 copies. The ' 3 ' allele entails a lower transcriptional $M A O-A$ activity, while the ' 3.5 ', ' 4 ', and ' 5 ' alleles are related to a higher activity of this gene. ${ }^{12}$

Interaction between environmental and genetic contributors to individual differences in the ability to cope with stress has not yet been fully elucidated, and conclusions drawn from various studies are sometimes inconsistent. ${ }^{13,14}$ Since it is an inherent part of everyday life, understanding how stress-coping is related to personality and genetic factors acquires special significance.

Stress-coping styles are analyzed in the context of a specific situation, disposition, and domain. One theory assumes that coping with a stressful event is a dynamic and situation-dependent process. According to another, it is a result of an individual style or disposition. The last concept states that the way of dealing with stress within one domain is relatively stable, but it may be different within others. ${ }^{15}$

A stress-coping style may have a significant effect on health and well-being. Available studies in the field usually do not take into account personality traits, and these may be crucial for the choice of a stress-coping strategy. ${ }^{16}$ Personality seems to play a special role in the psychology of stress and contributes to individual stress appraisal and stress-coping mechanisms. The 12-year follow-up study demonstrated high-stability coefficients for personality, which supports the theory that it may influence the effects of stress and efforts to cope with it. ${ }^{17}$

People do not have identical predispositions to react to stress stimuli. Complex interactions between personality and stress contribute to the development of individual potential, and the latter is manifested by different stresscoping styles and interpretation of life events. ${ }^{18}$

The aim of this study was to analyze the influence of genetic factors (the 5-HTT and MAO-A gene polymorphisms) on personality and stress-coping styles among healthy late reproductive age women.

\section{Materials and methods}

\section{Study design}

The study involved 345 healthy late reproductive age women from northwest Poland. All women had their follicle stimulating hormone and anti-Müllerian hormone levels determined; based on the results, they were classified as being in the late-reproductive stage.

\section{Setting and sample}

The criterion for inclusion in the study was the lack of endocrine, neoplastic, and psychiatric diseases. The criteria for exclusion from the study were abnormal smear test results, thyroid diseases and/or diabetes, cancer diseases, and mental diseases. Women with Axis I mental disorders according to the International Classification of Diseases-10 classification were excluded from the analysis by means of the Primary Care Evaluation of Mental Disorders questionnaire and a psychiatric examination.

\section{Ethical considerations}

All subjects gave informed written consent for participation in the project. The study was conducted in accordance with the Declaration of Helsinki, and the protocol was approved by the Bioethical Commission of the Pomeranian Medical University in Szczecin, Poland (permission number KB-0012/12/12).

\section{Measurements and instruments}

The first part of this study was survey-based and conducted using the following standardized research instruments:

The Coping Inventory for Stressful Situations (CISS), measuring the ability to cope with difficult situations. ${ }^{19}$ The results were classified as Task-Oriented Coping (TOC), Emotion-Oriented Coping (EOC), and AvoidanceOriented Coping (AOC). The latter style may take two forms, namely Distraction, ie, engaging in alternative activities, such as sleep, watching TV, etc., and Social Diversion that is seeking social contact. In the final assessment, we took into consideration sten norms for the 25-54 age 
bracket. The absolute stability and internal consistency of the CISS subscales were tested to assess the reliability of the Polish version of the CISS. The coefficients of the correlations between the subscale measurements were as follows: (TOC) $\mathrm{r}=0.75,(\mathrm{EOC}) \mathrm{r}=0.78,(\mathrm{AOC}) \mathrm{r}=0.80$, including engaging in alternative activities (Distraction) $\mathrm{r}=0.79$, and seeking social contact (Social Diversion) $r=0.73$. Analysis of the internal consistency of the CISS subscales demonstrated that the Cronbach $\alpha$ coefficient ranged from 0.82 to 0.88 for TOC and EOC, from 0.74 to 0.78 for AOC, and was 0.7 for Social Diversion. These results were regarded as satisfactory. $^{20}$

The Neuroticism-Extraversion-Openness Five-Factor Inventory (NEO-FFI), measuring personality traits, ${ }^{21}$ whose reliability and accuracy have been confirmed. This measure shows high internal consistency for each of the five subscales (the Cronbach $\alpha$ from 0.68 for openness to experience and agreeableness to 0.82 for conscientiousness). ${ }^{22}$

The second stage of the study was based on genetic testing, in which DNA was isolated from whole blood by Miller's salting-out method. ${ }^{23}$ DNA polymorphisms were identified by means of PCR. The purpose of the analysis was to amplify the fragment consisting of 2-5 repetitions of the 30-bp VNTR polymorphism in the MAO-A promoter region. The following primers were used $\mathrm{F}: 5^{\prime}$ CCC AGG CTG CTC CAG AAA 3', R: 5' GGA CCT GGG CAG TTG TGC 3'. The PCR consisted of an initial denaturing step at $95^{\circ} \mathrm{C}$ for 3 mins, followed by 34 cycles of denaturing at $94^{\circ} \mathrm{C}$ for $40 \mathrm{~s}$, annealing at $57^{\circ}$ $\mathrm{C}$ for $35 \mathrm{~s}$, and polymerization at $72^{\circ} \mathrm{C}$ for $50 \mathrm{~s}$, with a final elongation step at $72^{\circ} \mathrm{C}$ for 10 mins.

The sizes of the amplified fragments were as follows: $239,209,226$, and 269-bp. In the analysis of the 5-HTT polymorphism, the fragment including the 44-bp ins/del in the regulatory sequence (the presence or the lack of 44-bp) was amplified. The following primer sequences were used: HTT $F, 5^{\prime}$ GGC GTT GCC GCT CTG AAT GC $3^{\prime}$ and HTT $R, 5^{\prime}$ GAG GGA CTG AGC TGG ACA ACC AC $3^{\prime}$. The PCR consisted of an initial denaturing step at $94^{\circ} \mathrm{C}$ for 5 mins, followed by 30 cycles of denaturing at $94^{\circ} \mathrm{C}$ for 55 $\mathrm{s}$, annealing at $55^{\circ} \mathrm{C}$ for $50 \mathrm{~s}$, and polymerization at $72^{\circ} \mathrm{C}$ for $60 \mathrm{~s}$, with a final elongation step at $72^{\circ} \mathrm{C}$ for $10 \mathrm{mins}$. The sizes of the amplified fragments were $484 \mathrm{bp}$ and 528 bp. The PCR products were electrophoresed on 3\% agarose gel, which was followed by ethidium bromide staining to detect the alleles. The Hardy-Weinberg law for MAO-A was $p=0.952$ and for 5-HTT $p=1$.

\section{Data analysis}

Statistical analysis was performed using Statistica 7.1 PL. Spearman's rank R correlation coefficient was used to check for the strength of the relationships between the ordinal variables. The Shapiro-Wilk Test confirmed the lack of normal distribution of the variables analyzed.

Independent variables were tested using the one-way analysis of variance (Mann-Whitney $U$ test statistics). The results were regarded as statistically significant if $p \leq 0.05$.

The level of statistical significance was set as $\alpha=0.05$. The power calculated for all of the genetic tests exceeded 0.95 (power $>0.95$ ).

\section{Results}

The average age of the women in the study was $42.3 \pm 4.5$ years. More than half of them $(75.1 \%)$ had completed higher education, $22.6 \%$ had completed secondary education, $2.0 \%$ had vocational education, and $0.3 \%$ had primary education. Most of the women lived in cities with a population of over 100000 (72.5\%); $12.0 \%$ and $2.9 \%$ lived in rural areas and cities of up to 10,000 , respectively; the remainder $(12.8 \%)$ lived in cities with a population of up to 100,000 . The great majority of the participants had life partners $(75.1 \%)$.

The highest levels of a personality trait among the participants were noted for openness to experience $(\overline{\boldsymbol{x}}=6.47$ $\pm 1.71)$ and then agreeableness $(\overline{\boldsymbol{x}}=5.91 \pm 1.92)$; the lowest for neuroticism $(\overline{\boldsymbol{x}}=4.38 \pm 2.27$ ) (Table 1).

There were no statistically significant relationships between personality traits according to the NEO-FFI and the genotype distribution of the 30-bp VNTR polymorphism in the MAO-A promoter region $(p>0.05)$ (Table 2). The table does not show the $3 / 5$ genotypes due to a very small size of this group $(n=6)$. None of the personality traits was significantly related to the presence of the 5 allele.

Table I Personality structure according to the NEO-FFI

\begin{tabular}{|l|l|l|l|}
\hline $\begin{array}{l}\text { NEO-FFI } \\
\text { N=345 }\end{array}$ & $\bar{x} \pm$ SD & Min-Max & M (IQR) \\
\hline Neuroticism & $4.38 \pm 2.27$ & $1-10$ & $4(3)$ \\
Extroversion & $5.44 \pm 2.10$ & $1-10$ & $5(3)$ \\
Openness to experience & $6.47 \pm 1.7 \mathrm{I}$ & $\mathrm{I}-10$ & $7(\mathrm{I})$ \\
Agreeableness & $5.91 \pm 1.92$ & $\mathrm{I}-10$ & $6(2)$ \\
Conscientiousness & $5.46 \pm 2.02$ & $\mathrm{I}-10$ & $5(3)$ \\
\hline
\end{tabular}

Abbreviations: $\mathrm{N}$, number of participants; $\bar{x}$, arithmetic mean; Min, minimum value; Max, maximum value; $M$, median; IQR, interquartile range. 
Table 2 Analysis of the relationship between personality of the participants according to the NEO-FFI and the genotype distribution of the 30-bp VNTR polymorphism in the MAO-A promoter region

\begin{tabular}{|c|c|c|c|c|c|c|c|c|c|c|c|c|}
\hline \multirow{3}{*}{$\begin{array}{l}\text { NEO-FFI } \\
\text { N=339 }\end{array}$} & \multicolumn{6}{|l|}{ Genotype } & \multicolumn{6}{|c|}{ Genotype relationships } \\
\hline & \multicolumn{2}{|l|}{$\begin{array}{l}4 / 4 \\
n=\mid 42\end{array}$} & \multicolumn{2}{|l|}{$\begin{array}{l}4 / 3 \\
n=153\end{array}$} & \multicolumn{2}{|l|}{$\begin{array}{l}3 / 3 \\
n=44\end{array}$} & \multicolumn{2}{|c|}{$\begin{array}{l}4 / 4 \text { vs } 4 / 3 \\
+3 / 3\end{array}$} & \multicolumn{2}{|c|}{$\begin{array}{l}3 / 3 \text { vs } 4 / 4 \\
+4 / 3\end{array}$} & \multicolumn{2}{|c|}{$4 / 4$ vs $3 / 3$} \\
\hline & $\bar{x} \pm \mathbf{S D}$ & $\begin{array}{l}M \\
(I Q R)\end{array}$ & $\bar{x} \pm \mathbf{S D}$ & $\begin{array}{l}M \\
\text { (IQR) }\end{array}$ & $\bar{x} \pm \mathbf{S D}$ & $\begin{array}{l}M \\
(I Q R)\end{array}$ & $\mathbf{Z}$ & $p$ & $\mathbf{z}$ & $p$ & $\mathbf{Z}$ & $p$ \\
\hline Neuroticism & $4.50 \pm 2.26$ & $4(3)$ & $4.30 \pm 2.28$ & $4(3)$ & $4.29 \pm 2.22$ & $4(2.5)$ & 0.90 & 0.37 & 0.40 & 0.69 & 0.66 & 0.51 \\
\hline Extroversion & $5.36 \pm 2.12$ & $5(3)$ & $5.50 \pm 2.20$ & $5(3)$ & $5.39 \pm 1.78$ & $5(3)$ & -0.28 & 0.78 & 0.13 & 0.90 & 0.01 & 0.99 \\
\hline $\begin{array}{l}\text { Openness to } \\
\text { experience }\end{array}$ & $6.48 \pm 1.75$ & $7(2)$ & $6.51 \pm 1.63$ & $7(1)$ & $6.4 I \pm 1.78$ & $7(2)$ & -0.08 & 0.93 & 0.23 & 0.82 & 0.15 & 0.88 \\
\hline Agreeableness & $5.94 \pm 1.88$ & $6(2)$ & $5.98 \pm 1.77$ & $6(2)$ & $5.57 \pm 2.44$ & $6(4)$ & 0.10 & 0.92 & 0.69 & 0.49 & 0.57 & 0.57 \\
\hline Conscientiousness & $5.32 \pm 1.95$ & $5(3)$ & $5.53 \pm 2.02$ & $5(3)$ & $5.61 \pm 2.25$ & $5(3.5)$ & -0.90 & 0.37 & -0.19 & 0.85 & -0.42 & 0.67 \\
\hline
\end{tabular}

Abbreviations: $\mathrm{N}$, number of participants; $\mathrm{n}$, number of participants in genotypic subgroup; $\bar{x}$, arithmetic mean; $M$, median; IQR, interquartile range; $Z$, Mann-Whitney $U$ test statistics; $p$, level of significance.

There were statistically significant differences in the genotype distribution of the 44-bp VNTR polymorphism in the 5-HTT (SLC 6A4) promoter region for agreeableness. Women with the $\mathrm{s} / \mathrm{s}$ genotype differed significantly from those with the $1 / 1+1 / \mathrm{s}$ genotype $(p=0.02)$. Similarly, women with the $1 / 1$ genotype differed significantly from their counterparts with the $\mathrm{s} / \mathrm{s}$ genotype $(p \leq 0.05)$ (Table 3 ).

The analysis of stress-coping styles adopted by the participants demonstrated that a dominating style was TOC $(\overline{\boldsymbol{x}}=5.76 \pm 1.67)$. A dominating form of AOC was Social Diversion $(\overline{\boldsymbol{x}}=6.07 \pm 1.80)$ (Table 4).

There were no statistically significant relationships between stress-coping styles according to the CISS and the genotype distribution of the 30-bp VNTR polymorphism in the $M A O-A$ promoter region $(p>0.05)$ (Table 5). The table does not show the $3 / 5$ genotypes. None of the personality traits was significantly related to the presence of the 5 allele.

There were no statistically significant relationships between stress-coping styles adopted by the participants, according to the CISS and the genotype distribution of the 44-bp VNTR polymorphism in the 5-HTT (SLC 6A4) promoter region (Table 6).

We analyzed the influence of personality on the stresscoping style. Based on the results, all personality traits statistically significantly correlated with the choice of TOC and EOC. The only trait that showed a weak negative correlation with a TOC style was neuroticism $(-0.27)$; all other traits correlated positively - weak correlations with openness to experience $(0.22)$ and agreeableness $(0.12)$ were observed. The situation with EOC was opposite-this style strongly positively correlated with

Table 3 Analysis of the relationship between personality of the participants according to the NEO-FFI and the genotype distribution of the 44-bp VNTR polymorphism in the 5-HTT (SLC 6A4) promoter region

\begin{tabular}{|c|c|c|c|c|c|c|c|c|c|c|c|c|}
\hline \multirow{3}{*}{$\begin{array}{l}\text { NEO-FFI } \\
N=345\end{array}$} & \multicolumn{6}{|l|}{ Genotype } & \multicolumn{6}{|c|}{ Genotype relationships } \\
\hline & \multicolumn{2}{|l|}{$\begin{array}{l}1 / 1 \\
n=132\end{array}$} & \multicolumn{2}{|l|}{$\begin{array}{l}1 / s \\
n=163\end{array}$} & \multicolumn{2}{|l|}{$\begin{array}{l}s / s \\
n=50\end{array}$} & \multicolumn{2}{|c|}{ I/I vs I/s + s/s } & \multicolumn{2}{|c|}{$s / s$ vs $I / I+I / s$} & \multicolumn{2}{|c|}{$\mathrm{I} / \mathrm{l} \mathbf{v s} \mathbf{s} / \mathbf{s}$} \\
\hline & $\bar{x} \pm \mathbf{S D}$ & $\begin{array}{l}\text { M } \\
(\text { IQR) }\end{array}$ & $\bar{x} \pm \mathbf{S D}$ & $\begin{array}{l}\text { M } \\
(\text { IQR) }\end{array}$ & $\bar{x} \pm \mathbf{S D}$ & $\begin{array}{l}\text { M } \\
\text { (IQR) }\end{array}$ & $\mathbf{z}$ & $p$ & $\mathbf{Z}$ & $p$ & $\mathbf{Z}$ & $p$ \\
\hline Neuroticism & $4.39 \pm 2.24$ & $4(3)$ & $4.27 \pm 2.25$ & $4(2)$ & $4.74 \pm 2.41$ & $4(4)$ & -0.01 & 0.99 & -0.92 & 0.36 & -0.75 & 0.45 \\
\hline Extroversion & $5.32 \pm 1.94$ & $5.5(3)$ & $5.66 \pm 2.23$ & $5(4)$ & $5.04 \pm 2.05$ & $4(3)$ & -0.34 & 0.73 & 1.60 & 0.11 & 1.07 & 0.28 \\
\hline $\begin{array}{l}\text { Openness to } \\
\text { experience }\end{array}$ & $6.44 \pm 1.59$ & $7(1.5)$ & $6.59 \pm 1.78$ & $7(2)$ & $6.20 \pm 1.81$ & $6.5(2)$ & -0.43 & 0.67 & 1.40 & 0.16 & 0.96 & 0.33 \\
\hline Agreeableness & $5.95 \pm 1.88$ & $6(2)$ & $6.05 \pm 1.94$ & $6(2)$ & $5.32 \pm 1.86$ & $6(3)$ & 0.37 & 0.71 & 2.28 & 0.02 & 1.99 & 0.05 \\
\hline Conscientious-ness & $5.39 \pm 2.00$ & $5(3)$ & $5.59 \pm 2.06$ & $5(3)$ & $5.26 \pm 1.97$ & $5(3)$ & -0.15 & 0.88 & 0.96 & 0.34 & 0.73 & 0.46 \\
\hline
\end{tabular}

Abbreviations: $\mathrm{N}$, number of participants; $n$, number of participants in genotypic subgroup; $\bar{x}$, arithmetic mean; $M$, median; IQR, interquartile range; Z, Mann-Whitney $U$ test statistics; $p$, level of significance. 
Table 4 The structure of stress-coping styles adopted by the participants according to the CISS

\begin{tabular}{|l|l|l|l|}
\hline CISS & $\bar{x} \pm$ SD & Min-Max & M (IQR) \\
\hline Task-oriented coping (TOC) & $5.76 \pm 1.67$ & $1-10$ & $5(2)$ \\
Emotion-oriented coping (EOC) & $4.73 \pm 1.85$ & $1-10$ & $5(3)$ \\
Avoidance-oriented coping (AOC) & $5.55 \pm 1.58$ & $1-10$ & $5(I)$ \\
Engaging in alternative activities (Distraction) & $5.28 \pm 1.73$ & $1-10$ & $5(3)$ \\
Seeking social contact & $6.07 \pm 1.80$ & $1-10$ & $6(2)$ \\
(Social Diversion) & & & \\
\hline
\end{tabular}

Abbreviations: $N$, number of participants; $\bar{x}$, arithmetic mean; Min, minimum value; Max, maximum value; M, median; IQR, interquartile range.

Table 5 Analysis of the relationships between stress-coping styles adopted by the participants according to the CISS and the genotype distribution of the 30-bp VNTR polymorphism in the MAO promoter region

\begin{tabular}{|c|c|c|c|c|c|c|c|c|c|c|c|c|}
\hline \multirow{3}{*}{$\begin{array}{l}\text { CISS } \\
N=339\end{array}$} & \multicolumn{6}{|l|}{ Genotype } & \multicolumn{6}{|c|}{ Genotype relationships } \\
\hline & \multicolumn{2}{|l|}{$\begin{array}{l}4 / 4 \\
n=142\end{array}$} & \multicolumn{2}{|l|}{$\begin{array}{l}4 / 3 \\
n=153\end{array}$} & \multicolumn{2}{|l|}{$\begin{array}{l}3 / 3 \\
n=44\end{array}$} & \multicolumn{2}{|c|}{$\begin{array}{l}4 / 4 \text { vs } 4 / 3 \\
+3 / 3\end{array}$} & \multicolumn{2}{|c|}{$\begin{array}{l}3 / 3 \text { vs } 4 / 4 \\
+4 / 3\end{array}$} & \multicolumn{2}{|c|}{$4 / 4$ vs $3 / 3$} \\
\hline & $\bar{x} \pm \mathbf{S D}$ & $\begin{array}{l}\text { M } \\
(\text { IQR) }\end{array}$ & $\bar{x} \pm \mathbf{S D}$ & $\begin{array}{l}\text { M } \\
\text { (IQR) }\end{array}$ & $\bar{x} \pm$ SD & $\begin{array}{l}\text { M } \\
(\text { IQR) }\end{array}$ & $\mathbf{z}$ & $p$ & $\mathbf{Z}$ & $p$ & $\mathbf{Z}$ & $p$ \\
\hline $\begin{array}{l}\text { Task-oriented coping } \\
\text { (TOC) }\end{array}$ & $5.72 \pm 1.69$ & $6(2)$ & $5.81 \pm 1.69$ & $5(2)$ & $5.79 \pm 1.70$ & $5(2)$ & 0.02 & 0.98 & 0.39 & 0.69 & 0.34 & 0.73 \\
\hline $\begin{array}{l}\text { Emotion-oriented coping } \\
\text { (EOC) }\end{array}$ & $4.76 \pm 1.90$ & $5(3)$ & $4.65 \pm 1.82$ & $5(3)$ & $4.89 \pm 1.89$ & $4(3)$ & 0.40 & 0.69 & -0.52 & 0.60 & -0.29 & 0.77 \\
\hline $\begin{array}{l}\text { Avoidance-oriented cop- } \\
\text { ing }(A O C)\end{array}$ & $5.63 \pm 1.55$ & $5(2)$ & $5,52 \pm 1.63$ & $5(2)$ & $5,4 \mid \pm I .54$ & $5(1)$ & 0.76 & 0.44 & 0.90 & 0.37 & 1.03 & 0.30 \\
\hline $\begin{array}{l}\text { Engaging in alternative } \\
\text { activities (Distraction) }\end{array}$ & $5.27 \pm 1.73$ & $5(2)$ & $5.27 \pm 1.75$ & $5(3)$ & $5.25 \pm 1.73$ & $5(3)$ & 0.21 & 0.83 & 0.06 & 0.95 & 0.10 & 0.92 \\
\hline $\begin{array}{l}\text { Seeking social contact } \\
\text { (Social Diversion) }\end{array}$ & $6.22 \pm 1.66$ & $7(2)$ & $5.95 \pm 1.84$ & $6(2)$ & $6.00 \pm 2.04$ & $6.5(3)$ & 1.16 & 0.25 & 0.08 & 0.94 & 0.46 & 0.64 \\
\hline
\end{tabular}

Abbreviations: $N$, number of participants; $n$, number of participants in genotypic subgroup; $\bar{x}$, arithmetic mean; $M$, median; IQR, interquartile range; $Z$, Mann-Whitney $U$ test statistics; $p$, level of significance.

Table 6 Analysis of the relationships between stress-coping styles adopted by the participants according to the CISS and the genotype distribution of the 44-bp VNTR polymorphism in the 5-HTT (SLC 6A4) promoter region

\begin{tabular}{|c|c|c|c|c|c|c|c|c|c|c|c|c|}
\hline \multirow{3}{*}{$\begin{array}{l}\text { NEO-FFI } \\
N=345\end{array}$} & \multicolumn{6}{|l|}{ Genotype } & \multicolumn{6}{|c|}{ Genotype relationships } \\
\hline & \multicolumn{2}{|l|}{$\begin{array}{l}1 / 1 \\
n=132\end{array}$} & \multicolumn{2}{|l|}{$\begin{array}{l}1 / s \\
n=163\end{array}$} & \multicolumn{2}{|l|}{$\begin{array}{l}s / s \\
n=50\end{array}$} & \multicolumn{2}{|c|}{$\begin{array}{l}\mathrm{I} / \mathrm{vs} \mid / \mathrm{s}+\mathrm{s} / \\
\mathrm{s}\end{array}$} & \multicolumn{2}{|c|}{$\begin{array}{l}\text { s/s vs } I / I+ \\
I / s\end{array}$} & \multicolumn{2}{|c|}{ I/I vs s/s } \\
\hline & $\bar{x} \pm \mathbf{S D}$ & $\begin{array}{l}\text { M } \\
(\text { IQR) }\end{array}$ & $\bar{x} \pm \mathbf{S D}$ & $\begin{array}{l}\text { M } \\
(\text { IQR) }\end{array}$ & $\bar{x} \pm \mathbf{S D}$ & $\begin{array}{l}\text { M } \\
\text { (IQR) }\end{array}$ & $\mathbf{Z}$ & $p$ & $\mathbf{Z}$ & $p$ & $\mathbf{Z}$ & $p$ \\
\hline $\begin{array}{l}\text { Task-oriented coping } \\
\text { (TOC) }\end{array}$ & $5.60 \pm 1.59$ & $5(1.5)$ & $5.93 \pm 1.76$ & $5(2)$ & $5.66 \pm 1.73$ & $5(2)$ & -1.00 & 0.31 & 0.50 & 0.62 & -0.02 & 0.98 \\
\hline $\begin{array}{l}\text { Emotion-oriented coping } \\
\text { (EOC) }\end{array}$ & $4.86 \pm 1.91$ & $5(3)$ & $4.66 \pm 1.82$ & $5(3)$ & $4.58 \pm 1.83$ & $4.5(3)$ & 0.73 & 0.47 & 0.54 & 0.59 & 0.72 & 0.47 \\
\hline $\begin{array}{l}\text { Avoidance-oriented cop- } \\
\text { ing (AOC) }\end{array}$ & $5.60 \pm 1.57$ & $5(1.5)$ & $5.57 \pm 1.63$ & $5(2)$ & $5.34 \pm 1.48$ & $5(1)$ & 0.87 & 0.37 & 1.19 & 0.23 & 1.35 & 0.17 \\
\hline $\begin{array}{l}\text { Engaging in alternative } \\
\text { activities (Distraction) }\end{array}$ & $5.34 \pm 1.72$ & $5(3)$ & $5.28 \pm 1.77$ & $5(3)$ & $5.12 \pm 1.66$ & $5(2)$ & 0.55 & 0.58 & 0.99 & 0.32 & 1.01 & 0.31 \\
\hline $\begin{array}{l}\text { Seeking social contact } \\
\text { (Social Diversion) }\end{array}$ & $6.11 \pm 1.72$ & $7(2)$ & $6.11 \pm 1.92$ & $6(2)$ & $5.80 \pm 1.62$ & $6(2)$ & 0.54 & 0.59 & 1.16 & 0.24 & 1.13 & 0.26 \\
\hline
\end{tabular}

Abbreviations: $\mathrm{N}$, number of participants; $n$, number of participants in genotypic subgroup; $\bar{x}$, arithmetic mean; M, median; IQR, interquartile range; $\mathrm{Z}$, Mann-Whitney $\mathrm{U}$ test statistics; $p$, level of significance. 
neuroticism (0.74) and negatively with other personality traits. An AOC style showed a weak positive correlation with extroversion (0.21) and a weak negative correlation with agreeableness $(-0.14)$. AOC takes two forms: engaging in alternative activities (Distraction) and seeking social contact (Social Diversion). There was a weak positive correlation between Distraction and neuroticism (0.26), and a weak negative correlation between Distraction and agreeableness $(-0.25)$. Social Diversion showed a weak negative correlation $(-0.31)$ with neuroticism, and a weak positive correlation with extroversion $(0.24)$, openness to experience $(0.24)$, and agreeableness (0.21) (Table 7).

\section{Discussion}

The influence of genetic factors on personality and stresscoping styles in healthy late reproductive age women is an innovative research direction. Our findings will improve the understanding and extend the knowledge of these issues.

Studies of personality and stress-coping styles show a certain tendency or predisposition for choosing particular stress-coping styles depending on personality traits. ${ }^{24,25}$ Numerous authors interested in the relationship between genetic factors and personality traits have reported ambiguous results, suggesting that other modifiers also contribute to this correlation. The analysis conducted by Samochowiec et al (2004) demonstrated that one of such elements is sex. They noticed that male carriers of the 3-repeat variant of the $M A O-A$ had definitely lower levels of openness to experience; a similar relationship was not observed in women. ${ }^{26}$ The study of 406 adult patients with major mental diseases conducted in order to check for the NEO-FFI stability demonstrated that the NEO-FFI scales were stable for sex, the level of extroversion depended on age, and neuroticism was slightly higher in people with lower levels of education. $^{27}$ Eley et al (2003) provided evidence that the high activity 30-bp VNTR polymorphism in the MAO-A promoter region enhanced the expression of neuroticism; however, it was only true for men. ${ }^{28}$ In many studies, the relationship between the gene variant, personality traits, and pathological behavior, such as aggression, alcoholism, or violence, results from the combination of genetic predisposition and adverse environmental factors, for example, childhood trauma. $^{29}$ The analysis of 249 veterans who developed chronic and current combat-related PTSD did not demonstrate the relationship between the presence of the MAO-A gene variant and the severity of selected psychotic symptoms resulting from exposure to stress. ${ }^{9}$ In our study, no significant relationships between the presence of a specific genotype of the 30-bp VNTR polymorphism in the MAO-A promoter region and personality domains were observed. The lack of such associations may result from the fact that a study sample did not include individuals with mental disorders. It seems reasonable to conduct further research in this field, including a group of subjects with mental dysfunctions.

The available publications on personality traits and the 5-HTT gene polymorphism show a link between these two; in most cases, this relationship is also analyzed in terms of the influence of environmental factors. ${ }^{30}$ The research of Caspi et al (2003) confirmed that regardless of their gender, carriers of the "s" allele had more severe depressive symptoms and were more inclined to attempt suicide as a consequence of stressful life events. ${ }^{31}$ The findings reported by Hammen et al (2010) suggest that the combination of genetic factors (the 5-HTTLPR "s" allele) and environmental stress (stressful family environment) increases the risk of

Table 7 Correlations between the NEO-FFI and the CISS scales

\begin{tabular}{|c|c|c|c|c|c|c|c|c|c|c|}
\hline \multirow{3}{*}{$\begin{array}{l}\text { NEO-FFI } \\
N=345\end{array}$} & \multicolumn{10}{|c|}{ CISS scales } \\
\hline & \multicolumn{2}{|c|}{$\begin{array}{l}\text { Task-oriented } \\
\text { coping (TOC) }\end{array}$} & \multicolumn{2}{|c|}{$\begin{array}{l}\text { Emotion- } \\
\text { oriented coping } \\
\text { (EOC) }\end{array}$} & \multicolumn{2}{|c|}{$\begin{array}{l}\text { Avoidance- } \\
\text { oriented coping } \\
\text { (AOC) }\end{array}$} & \multicolumn{2}{|c|}{$\begin{array}{l}\text { Engaging in alterna- } \\
\text { tive activities } \\
\text { (Distraction) }\end{array}$} & \multicolumn{2}{|c|}{$\begin{array}{l}\text { Seeking social } \\
\text { contact (Social } \\
\text { Diversion) }\end{array}$} \\
\hline & $\mathbf{R}$ & p & $\mathbf{R}$ & $p$ & $\mathbf{R}$ & $p$ & $\mathbf{R}$ & $p$ & $\mathbf{R}$ & $p$ \\
\hline Neuroticism & -0.27 & 0.00 & 0.74 & 0.00 & 0.04 & 0.41 & 0.26 & 0.00 & -0.31 & 0.00 \\
\hline Extroversion & 0.44 & 0.00 & -0.20 & 0.00 & 0.21 & 0.00 & 0.07 & 0.21 & 0.24 & 0.00 \\
\hline Openness to experience & 0.22 & 0.00 & -0.16 & 0.00 & 0.04 & 0.42 & -0.08 & 0.12 & 0.24 & 0.00 \\
\hline Agreeableness & 0.12 & 0.02 & -0.42 & 0.00 & -0.14 & 0.01 & -0.25 & 0.00 & 0.21 & 0.00 \\
\hline Conscientiousness & 0.46 & 0.00 & -0.13 & 0.02 & 0.02 & 0.73 & -0.02 & 0.63 & 0.00 & 0.96 \\
\hline
\end{tabular}

Abbreviations: N, number of participants; R, Spearman's rank correlation coefficient; $p$, level of significance. 
depressive disorders in women. ${ }^{4}$ Similar conclusions were drawn by Katsuyama et al (2009), who analyzed the levels of depressive mood experienced by Japanese employees as a consequence of work-related stress. They found that disorders resulting from the reaction to stress were significantly more severe in carriers of $\mathrm{s} / \mathrm{s}$ than in those who had the $\mathrm{s} / 1$ or $1 / 1$ variants of the 5 -HTT gene. ${ }^{2}$

In our study, the only personality trait related to the genotype was agreeableness. We noticed that carriers of the $\mathrm{s} / \mathrm{s}$ genotype had lower levels of agreeableness than those with the $1 / 1$ and the $1 / \mathrm{s}$ genotypes. A significant impact of the genotype of the 5-HTT gene polymorphism on other personality domains or the choice of a stress-coping style was not observed.

Carrying out further research in this field seems reasonable; however, it would be more interesting if a sample size was bigger, and subjects with specific mental disorders, such as depression, anxiety, or addictions, were included. In light of the literature, it is also important to analyze the influence of environmental factors on the expression of personality traits and their influence on the choice of a stress-coping style.

\section{Conclusion}

Some of personality traits are genetically determined. The choice of a stress-coping style is significantly influenced by personality traits. A direct influence of genetic factors on the choice of a stress-coping style was not confirmed in our study.

Stress wreaks havoc on both our emotional well-being and our physical health. Therefore, the ability to deal with stress efficiently is of the greatest importance. The knowledge of how personality traits influence the choice of stress-coping styles could be used to help people deal with stress successfully even if they are inclined by nature to adopt ineffective stress-coping strategies.

\section{Acknowledgment}

Financial resources for the project and funds for covering the costs for publication came exclusively from the Pomeranian Medical University in Szczecin.

\section{Disclosure}

The authors report no conflicts of interest in this work.

\section{References}

1. Mayor E. Gender roles and traits in stress and health. Front Psychol. 2015;9(6):779.

2. Katsuyama H, Tomita M, Okuyama T, et al. 5HTT polymorphisms are associated with job stress in Japanese workers. Leg Med. 2009;11 (1):473-476. doi:10.1016/j.legalmed.2009.01.081
3. Glei DA, Goldman N, Liu I-W, et al. Sex differences in trajectories of depressive symptoms among older Taiwanese: the contribution of selected stressors and social factors. Aging Ment Health. 2013;17 (6):773-783. doi:10.1080/13607863.2013.781119

4. Hammen C, Brennan PA, Keenan-Miller D, et al. Chronic and acute stress, gender, and serotonin transporter gene-environment interactions predicting depression symptoms in youth. J Child Psychol Psychiatry. 2010;51(2):180-187. doi:10.1111/j.1469-7610.2009.02177.x

5. Mushtaq R, Shoib S, Shah T, et al. 5-Hydroxy tryptamine transporter (5HTT) gene promoter region polymorphism in anxiety and depressive disorders. MJIRI. 2014;11(28):127.

6. Jurczak A, Szkup M, Wieder-Huszla S, et al. The assessment of the relationship between personality, the presence of the 5HTT and MAO-A polymorphisms, and the severity of climacteric and depressive symptoms in postmenopausal women. Arch Womens Ment Health. 2015;18(4):613-624. doi:10.1007/s00737-014-0485-9

7. Smirnova T, Spivak DL, Zakharchuk AG, et al. Distribution of serotonin transporter 5-HTTLPR gene polymorphism in population of the North-West of Russia. Adv Gerontol. 2012;25(1):29-34.

8. Fowler JS, Logan J, Shumay E, et al. Monoamine oxidase: radiotracer chemistry and human studies. J Labelled Compd Rad. 2015;58 (3):51-64. doi:10.1002/jlcr.3247

9. Svob Strac D, Kovacic Petrovic Z, Nikolac Perkovic M, et al. Platelet monoamine oxidase type $\mathrm{B}, \mathrm{MAOB}$ intron 13 and MAOA-uVNTR polymorphism and symptoms of post-traumatic stress disorder. Stress. 2016;26:1-12.

10. Brunner HG, Nelen M, Breakefield XO, et al. Abnormal behavior associated with a point mutation in the structural gene for monoamine oxidase. Science. 1993;262:578-580. doi:10.1126/science.8211186

11. Sabol SZ, Hu S, Hamer D. A functional polymorphism in the monoamine oxidase A gene promoter. Hum Genet. 1998;103:273-279. doi:10.1007/s004390050816

12. Denney RM, Koch H, Craig IW. Association between monoamine oxidase A activity in human male skin fibroblasts and genotype of the MAOA promoter-associated variable number tandem repeat. Hum Genet. 1999;105:542-551.

13. Monroe SM, Reid MW. Gene-environment interactions in depression research. Genetic polymorphisms and life-stress polyprocedures. Psychol Sci. 2008;19(10):947-956. doi:10.1111/j.1467-9280.2008. 02181.x

14. Risch N, Herrell R, Lehner T. Interaction between the serotonin transporter gene (5-HTTLPR), stressful life events, and risk of depression. JAMA. 2009;301(23):2462-2471. doi:10.1001/jama.2009.878

15. Gregório GW, Brands I, Stapert S, et al. Assessments of coping after acquired brain injury: a systematic review of instrument conceptualization, feasibility, and psychometric properties. J Head Trauma Rehabil. 2014;29(3):30-42. doi:10.1097/HTR.0b013e31828f93db

16. Watanabe K, Yokoyama K, Furukawa TA. Reliability and validity of the Japanese version of the coping inventory for adults for stressful situations in healthy people. Psychol Rep. 2015;116b(2):447-469.

17. McCrae RR, Costa PT Jr. Validation of the five factor model of personality across instruments and observers. J Per Soc Psychol. 1985;13:653-665.

18. Vollrath M. Personality and stress. Scand J Psychol. 2001;42:335-347. doi:10.1111/1467-9450.00245

19. Krau E, Ed. Self-realization, Success and Adjustment. New York (NY): Praeger; 1989.

20. Jabłońska A. Trafność teoretyczna Kwestionariusza radzenia sobie w sytuacjach stresowych CISS ze szczególnym uwzględnieniem trafności teoretycznej skali stylu skoncentrowanego na unikaniu. Testy Psychologiczne w Praktyce i Badaniach. 2015;01:31-51.

21. McCrae RR, Costa PT Jr. Personality, coping, and coping effectiveness in an adult sample. J Pers. 1986;54:385-405. doi:10.1111/j.1467-6494.1986. tb00401.x

22. Radoń S. Pięciowymiarowy kwestionariusz uważności: polska adaptacja. Roczniki Psychologiczne. 2014;4:711-735. 
23. Miller S, Dykes D, Plesky H. A simple salting out procedure for extracting DNA from human nucleated cells. Nucleic Acids Res. 1988;16:1215. doi:10.1093/nar/16.3.1215

24. Bosworth HB, Feaganes JR, Vitaliano P, et al. Personality and coping with a common stressor: cardiac catheterization. J Behav Med. 2001;24(1):17-31. doi:10.1023/A:1005682303815

25. Lecic-Tosevski D, Vukovic O, Stepanovic J. Stress and personality. Psychiatriki. 2011;22(4):290-297.

26. Samochowiec J, Syrek S, Michał P. Polymorphisms in the serotonin transporter and monoamine oxidase A genes and their relationship to personality traits measured by the Temperament and Character Inventory and NEO Five-Factor Inventory in healthy volunteers. Neuropsychobiology. 2004;50(2):174-181. doi:10.1159/000079111

27. Mikołajczyk E, Zietek J, Samochowiec A. Personality dimensions measured using the Temperament and Character Inventory (TCI) and NEO-FFI on a Polish sample. Int J Methods Psychiatr Res. 2008;17 (4):210-219. doi:10.1002/mpr.270
28. Eley TC, Tahir E, Angleitner A. Association analysis of MAOA and COMT with neuroticism assessed by peers. Am J Med Genet $B$ Neuropsychiatr Genet. 2003;120B(1):90-96. doi:10.1002/ajmg. b. 20046

29. Verhoeven FE, Booij L, Kruijt AW, et al. The effects of MAOA genotype, childhood trauma, and sex on trait and state-dependent aggression. Brain Behav. 2012;2(6):806-813. doi:10.1002/ brb3.96

30. Paaver M, Kurrikoff T, Nordquist N, et al. The effect of 5-HTT gene promoter polymorphism on impulsivity depends on family relations in girls. Prog Neuropsychopharmacol Biol Psychiatry. 2008;32 (5):1263-1268. doi:10.1016/j.pnpbp.2008.02.004

31. Caspi A, Sugden K, Moffitt TE. Influence of life stress on depression: moderation by a polymorphism in the 5-HTT gene. Science. 2003;301:386-899. doi:10.1126/science.1083968
Clinical Interventions in Aging

\section{Publish your work in this journal}

Clinical Interventions in Aging is an international, peer-reviewed journal focusing on evidence-based reports on the value or lack thereof of treatments intended to prevent or delay the onset of maladaptive correlates of aging in human beings. This journal is indexed on PubMed Central, MedLine, CAS, Scopus and the Elsevier

\section{Dovepress}

Bibliographic databases. The manuscript management system is completely online and includes a very quick and fair peer-review system, which is all easy to use. Visit http://www.dovepress.com/ testimonials.php to read real quotes from published authors. 